\title{
Growth Effects of International Integration in Southeastern Europe: Implications on FDI and Trade
}

\begin{abstract}
Jonel Kristo
Doi:10.5901/mjss.2014.v5n8p178

Center for Economic and Business Education'1, Tirana, Albania

Abstract

International integration is explored through a sample of 9 countries in Southeastern Europe for a period of 13 years, from 1996 to 2009. A panel data approach is taken, using fixed effects and a within estimator model. The central questions of this study are to assess the directional effect of international integration on growth, to study the channels of transmission of such growth, and to measure the intensity of these relationships. The findings suggest that: an integrated region benefits more from trade in the form of exports, and less so from imports. Foreign direct investments are attracted to an integrated region more intensively, although inter-regional $R \& D$ expenditures in cost-oriented industries are not influencing growth to a considerable extent. The difference between high-tech and low-tech investments might give more conclusive results regarding this matter. For an integrated region where FDI and trade are intense, a competent and readily available labor force is found to affect growth incrementally more.
\end{abstract}

\section{Introduction}

With the positive experience of cluster-based industrialization in places such as Silicon Valley in the San Francisco Bay Area in Northern California, or the many other integrated economies around the world, researchers have sought to measure the marginal effect of such economic structures on growth. Do economies grow substantially better - both in volume and speed - if they seek policy and spatial coordination of the relevant factors of production ${ }^{2}$ ?

Crozet and Koenig (2007) have attempted to answer the second part of this question by looking at data for EU regions over the 1980-2000 time span. They conclude - through the exploration of the effect of spatial concentration of economic activity on growth performance - that regions with a more uneven internal spatial distribution of production appear to grow faster. Our research differs from Crozet and Koenig's (2007) study in that we explore this relationship for non-EU countries, where institutional legacies and levels of economic development are substantially different. Also, Henderson (2003) and Ades \& Glaeser (1995) seem to focus their research on the effect of integration in terms of urbanization on growth, and Brulhart and Sbergami (2008) consider intra-country spatial integration while trying to explore the causal link of the latter to growth. Regional integration is gaining significance in an era where globalization and uniontype integration (as the EU) is rendering national borders less and less significant. In this sense, regional factors are becoming determinants of investment decisions (Pelegrin and Bolance, 2008), thus contributing further to the proved conviction of foreign direct investments as one factor of growth. ${ }^{3}$ Supporting the new economic growth model of greater utility through spatial proximity, economic integration reflects Baldwin and Martin's (2004) belief that regional economic coordination is conducive to such growth. If significant interaction can be proved between growth and economic integration, than chances are that public policy will be oriented towards departing from the classical regional approach to growth, and instead embrace growth promotion at the national and international level (Martin, 1999). Pelegrin and Bolance (2008) estimate this interaction to be valid from an inner-country point of view. They assert that in the Spanish manufacturing sector, economic integration proves to be a determinant location factor for FDI, especially in the context of

\footnotetext{
${ }^{1}$ Disclaimer: The statements made in this paper are the author's own responsibility, and do not necessarily reflect the opinion of the Center for Economic and Business Education.

${ }^{2}$ The traditional factors of production such as land and labor are characterized by greater immobility, so they can not be significantly associated with the need of cluster-based development to move resources in the most productive regions. For this reason, and for the scope of this paper, we have adjusted the definition of "factors of production" to include those competencies and resource endowments of firms and regions, which act as relevant factors in entrepreneurial decision making. Pelegrin and Bolance (2008) considered factors such as market demand, industrial density, labor cost, human capital availability, and the presence of innovation systems as relevant factors of production under international integration. Also, the term production refers to the general process of turning inputs into outputs, and does not refer necessarily to this process in an exclusive manufacturing sense.

${ }^{3}$ Dees (1998); De Mello (1996); Blomstrom, Lipsey, and Zejan (1994); Borenzstein, De Gregorio, and Lee (1995); Balasubramayam, Salisu, and Sapsford (1996 and 1999); Kawai (1994). There should be some consideration given to an alternative point of view in this regard given by Bosworth and Collins (1999), who find that positive effect of FDI on domestic fixed investment tends to fall off significantly when more country characteristics are controlled for. Rodrik (1999) argues along those same lines.
} 
same industry activity. Fujita and Krugman (2004) pose a kind of vicious circle between consumers, producers, and market thickness when they describe the circular causation of forward linkages as the incentives of workers to be close to the producers, and backward linkages as the incentive of producers to concentrate where the market is larger. In an earlier contribution, the centripetal forces ${ }^{4}$ identified by Fujita et al. (1999) promote shortening of the supply chain due to geographical proximity. In light of increased competitive spoils, firms and workers saturate the region lured by higher wages and more efficient resource allocation. When this saturation happens - which, according to Krugman's (1991) core-periphery model causes centrifugal forces to emerge - factor immobility and congestion diseconomies bring in a thinning-out effect of firms' dispersal in space. On similar lines, it could be hypothesized that the temporary utility derived from an internationally integrated economy in equilibrium, at a time when centrifugal forces are still dormant and markets are in the early stages of their business cycles, causes greater developmental effect on economic growth. Williamson (1965) asserts that 'a poorly developed infrastructure should force higher concentration' as a means of dealing with the lack of facilitative supply chain instruments, rather than use economic concentration as a technique to gain marginal growth from exploiting and/or augmenting industry competencies in thicker markets. Moreover, following that same logic of natural cyclical development, there is a change in behavior towards growth when the opportunity cost of nonintegration is so high that it makes sense to pursue the opposite in quest of higher societal returns at affordable temporary negative costs.

\section{Theoretical Framework of the Research}

This cyclical approach to development indirectly reflects one of the goals of this paper: to establish empirical evidence that international integration can act as an independent factor of marginal growth and, therefore, as a driver of future investment decisions. The novelty of this paper rests in considering the effect of inter-country decentralization of production functions around those regions ${ }^{5}$ that can complement each other with integration (or coordination) of their respective factors of production. This goal redefines the concept of country-specific comparative advantages, and postulates the idea that countries, if able to complement each other and form a complete entrepreneurial supply chain, can better attract investments to bring the entire region in an elevated state of growth. This "countryhoodedness" promotes a cross border configuration of economic activities and the authors hypothesize that there are several positive effects to be expected. First, it could be possible that by slowing down perfect competition, the process of diminishing returns could be reversed to an earlier stage so that, at least temporarily, industries can compete with positive profits (vs. normal profits). This poses a controversial point, however, and one could ask about the balance that should be required between promoting intentional tardiness of perfect competition and the deadweight loss to society from an imperfect free market economy. The literature in this regard is very limited, to say the least, but congestion externalities formalized by Krugman (1991) may call for authorities and policy makers to not promote international integration on the shoulders of higher net negative costs to society. Second, the pragmatic concept of cross border pooling of resources facilitates the implementation of systems that promote Narula and Zanfei's (2004) idea that the foundations of the competitive advantage no longer reside in only one country, and rightfully so. The economic theory of comparative advantage has traditionally promoted a country-exclusive exploitation of specialization of production to compete with other countries adhering to the same school of thought. When countries realize that they don't poses a natural or farmed ability to comparatively advance, then they turn to international trade for fulfilling their consumption needs, which should have turned into an almost natural reaction by now. But this disarmament does not have to happen this fast, or at least not until the international integration option is exhausted as a potential alternative. Narula and Zanfei (2004) also recognize the lack of joint velocity movement between technological specialization of countries and innovation needs of firms, leading one to think that the gap could be closed by physically expanding the innovation system further to include additional cross border areas of technological advancement ${ }^{6}$. Maurseth and Verspagen (2002) explore this topic in the required direction. They found that innovation systems in European regions, if dispersed geographically, have a negative impact on knowledge flows and R\&D activity, thus making it impossible to benefit from Criuscolo's (2005) asset-exploiting (use of firm own assets in a foreign location) and asset-augmenting (when firms locate elsewhere to improve, acquire, or create

\footnotetext{
${ }^{4}$ Comprised by (1) Forward and backward linkages; (2) thick markets; (3) knowledge spillovers

${ }^{5}$ The word regions used for the scope of this paper refers to countries that comprise one global region, not to cities within a specific country. An example would be the Southeastern European region, which is relevant to this paper. Countries belonging to the SEE region, according to the definition given in the 1999 Stability Pact of the European Bank for Reconstruction and Development, slightly modified for this paper, are: Albania, Bosnia \& Herzegovina, Bulgaria, Croatia, FYROM, Italy, Greece, Romania, and Serbia.

${ }^{6}$ In this section we mention technological advancement exclusively due to the robust results of Pelegrin and Bolance's (2008) estimation that the presence of a local innovation system in a country (in their case the country is Spain) is always a significant variable in determining FDI location, regardless of industry sector.
} 
new technological assets) activities. But this raises an important question from an international perspective: if a country does not hold the necessary infrastructure to act as an innovation system by itself, can it integrate internationally with neighboring countries and offer a joint scientific base (among other complementary factors of production) to foreign investors? From a purely infrastructural perspective, the answer is yes. It is possible to invest in erecting a cross border scientific exchange network that covers entire countries with proximity to each other. Even from a purely intellectual perspective, the answer is still yes, and we are hopefully able to realize the marginal benefits of additional knowledge. However, the main question should be if such an investment makes economic sense from a competitive growth perspective, and do firms find it viable to welcome such initiative in the cluster. Shavier and Flyer (2000) argue that when firms are heterogeneous, international integration is expected to be characterized by adverse selection. They follow up on this idea by suggesting that when firms already have the best technologies, human capital, training programs, supplier and distribution network, they will competitively suffer when these factors spill over to their competitors. Conversely, they continue, firms with the weakest technologies, human capital, training programs, suppliers, or distributors have little to loose and a lot to gain; therefore, these firms are motivated to integrate. Subsequently, the issue that this logic presents is to establish whether companies in the SEE region belong to the first or the second group, so that we can be sure of the presence of incentives to integrate economically.

The net national income effect of higher FDI inflows caused by larger economic integration efforts does not seem to have been the subject of much research, although a considerable number of studies have explored various forms of location determinants of FDI. ${ }^{7}$ In addition, Pelegrin and Bolance (2008) assert that, for certain industries (chemicals, transport equipment, electric and electronic equipment), economic integration matters mainly due to competitive responsiveness towards low labor costs, human capital availability, and same industry convergence. On the other hand, they state that cost-oriented industries, such as food and beverages and paper, printing and publishing, value endowment more than regional integration. ${ }^{8}$ In this context, does international integration affect growth, and if so, to what extent?

\section{Empirical Framework and Methodology}

For all common purposes, the variables and methodology in the paper follow the general structure of Economidou, et al (2006), although departures and adaptations from that structure are made to adjust to the theoretical framework of interest in this particular paper. With the questions laid out in the preceding section, the main hypothesis of this paper becomes the following:

Hypothesis: The net economic effect of international integration is positive when the panel sample is constrained into a cross-border region with geographical proximity and other similarities

$$
\sum_{i=1}^{9} w_{i}{ }^{*} E_{i \text { int }}-\sum_{i=1}^{9} w_{i}{ }^{*} E_{\text {minti }}>0: \Delta E>0
$$

Where $E_{\text {int }}$ is economic growth under international integration, $E_{\text {niint }}$ is economic growth with no international integration, and $\Delta E$ is the net effect of this difference. A weighted average approach is used to account for country size and resource abundance.

The implications of international integration on economic growth are estimated through the following model:

$y_{i t}=\alpha+\beta C_{i t}+\varsigma T_{i t}+v_{i t}+\varepsilon_{i t}$

The model has two explanatory parts for the dependent variable growth rate of GDP per capita expressed by $y_{i t}$ : a group of control variables that measure the state of the economy for country $i$ captured by $\beta C_{i t}$, and a group of international integration variables captured by $\varsigma T_{i t}$. What is left is a country specific error term, ${ }^{{ }_{i t}}$, and a stochastic error term, ${ }^{{ }_{i t}}$. All variables enter the model in logarithmic form under the safe supposition that the variables affect growth nonlinearly.

\subsection{Variables}

Following several empirical growth studies, the state-of-the-economy group of variables includes: (1) gross enrollment ratio for all secondary schooling programs (GERS), (2) employment to population ratio (ETPR), (3) general government

\footnotetext{
${ }^{7}$ Scaperlanda and Balough (1983); Culem (1988); Thiran and Yamawaki (1995); Hill and Munday (1991, 1992); Mariotti and Piscitello (1995); Guimaraes et al (2000); Egea and Lopez Pueyo (1991); Pelegrin (2002);

${ }^{8}$ This logic is important because it takes into consideration the possibility of SEE economies being cost-oriented, and if so, it can be that they won't value integration as much in face of factor endowments. In addition, Brulhart and Sbergami (2008) also pose an income constraint that is valuable for the level of economic growth in SEE: that integration looses its power when real gross income per capita goes above $\$ 10,000$.
} 
expenditure share of GDP (GEXP), (4) annual population growth rate (POPG), and (5) gross expenditures on R\&D as a share of GDP (GERD). The sign on GERS is expected to be positive because a better educated population enhances a country's ability to absorb new technologies and innovate, which makes it an important growth factor (Lucas, 1993, Krueger and Lindahl, 2001). This variable is used to proxy for country i's level of human capital stock.

The ratio of total employment to population is used here as a proxy for labor force availability and it gives a fast indication of how frictional the labor market is for country $i$. The logic here is that the higher the rate of employment and the higher the employment insecurity, the more inelastic the labor market. This will harden recruiting efforts of new FDIs when entering country $i$, The sign on ETPR is expected to be negative, because the higher the levels of labor force utilization, the harder it will be for companies to find labor for hire that isn't already allocated in existing ventures, thus adding to start-up costs for new FDIs.

Government expenditure is a dilemmatic indicator. Net unproductive government spending is expected to affect growth negatively. However, Barro and Sala-i-Martin (1995) and Economidou et.al. (2006) show that the contribution of governments on education, health, public works, or other forms of productive capital can promote growth and helps explain cross-country differences in per capita income. Therefore, based on former findings in the literature, the sign on GEXP is expected to be positive.

Population growth supposedly imposes a negative burden on society, and therefore the sign on POPG is expected to be negative. Economidou, et.al. (2006) explain that higher fertility rates imply that more resources should be devoted to raising the newborn population rather than producing new goods, thus reducing income growth. Neoclassical growth models assume the same thing, that a higher population growth rate impacts negatively the steady-state level of output per worker. Note here however, that demographic indicators like this might need considerably more time to incorporate any significant information in the data.

Lastly in this group is the ratio of gross expenditures on research and development over GDP, which is used here to measure the intensity of new knowledge generation. The sign on this variable is expected to be positive. Firms that operate in an interregional investment mode value knowledge and R\&D intensity may be an attraction factor for investors (Driffield and Munday, 2000), thus positively contributing to growth. We do not distinguish here between high-tech or lowtech expenses.

The second group of control variables includes measures of international integration: (1) net inflows of FDI as a share of GDP (FDIR), which measures all inward flow of FDI as a share of recipient's country GDP, (2) volume of trade as a share of GDP (TRAD), (3) trade intensity index (TII), which is used to determine whether the value of trade between two countries is greater or smaller than would be expected on the basis of their importance in world trade, and (4) intra industry trade index (IIT), which measures the level of net gains from specialization in different industries across countries, and that a participating country is increasing or decreasing its integration in the world economy. Ideally, this measure would give a preliminary indication whether there is any same-industry convergence happening in SEE.

The estimated coefficient of FDIR is expected to be positive, because FDI are long seen as the channel through which new technologies and knowledge are transferred and spilled over between countries. However, UNCTAD (1999) argue that FDI can be positively or negatively associated with growth depending on the variables that enter an estimation equation, so such assumption about the sign of FDIR is taken with a note of caution.

Trade is assumed to affect growth positively, and is used here as a measure of a country's openness to the rest of the world. A core question that is raised here is that one can not reasonably assume that imports and exports are equally important to income growth (Haveman, et. al., 2001). Therefore, TRAD is dissected into exports as a share of GDP (EXP) and imports as a share of GDP (IMP). Trade (be it exports only or imports only) is considered a growth-enhancing interaction, and more open economies should exhibit higher growth rates (Frankel and Rommer, 1999).

The trade intensity index is defined as the share of one country's exports going to a partner divided by the share of world exports to the partner. An index that is more (less) than one indicates a bilateral trade flow that is larger (smaller) than expected given the partner country's importance in world trade. The estimated coefficient on TII is expected to be positive, conduit to the logic that larger trade flows affect income growth positively.

Lastly for this group, the intra industry trade index is used to measure the level of integration of a participating country into the world economy. Some analyses of factors influencing the success or failure of efforts to promote industrialization and growth conclude that a growing level of intra industry trade plays an important positive role. Intra industry exchange produces extra gains from international trade over and above those associated with comparative advantage because it allows a country to exploit larger markets (Hoekman, et. al., 2003). With this said, the estimated coefficient is expected to be positive. The TII and IIT are two trade indices developed in the World Bank's Handbook on Development, Trade, and the WTO (Hoekman, et. al., 2003). The indices are mathematically defined as follows, where $x_{i j}$ and $X_{w j}$ are country i's and world exports to country $j, X_{i t}$ and $X_{w t}$ are country i's total exports and total world exports, 
respectively, $X_{j k}$ and $M_{j k}$ represent exports and imports of total products in country $j$ to and from country $k$.

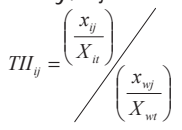

\&

$$
I I T_{j k}=1-\left[\sum\left|X_{j k}-M_{j k}\right| /\left(X_{j k}+M_{j k}\right)\right]
$$

Tables 1 and 2 below shows the values of these two indices for Albania.

Table 1: Trade Intensity Index of Albania with Respective Countries

\begin{tabular}{|c|c|c|c|c|c|c|c|c|}
\hline Year & $\mathrm{BiH}$ & Bulgaria & Croatia & Greece & Italy & FÝROM & Romania & Serbia \\
\hline 1996 & 0.109 & 0.011 & 0.247 & 1.293 & 0.786 & 5.340 & 0.017 & 0.053 \\
\hline 1997 & 0.119 & 0.010 & 1.236 & 2.037 & 0.637 & 3.980 & 0.009 & 0.062 \\
\hline 1998 & 0.101 & 0.026 & 0.195 & 1.778 & 0.757 & 2.126 & 0.029 & 0.007 \\
\hline 1999 & 0.091 & 0.004 & 0.038 & 1.170 & 0.835 & 1.766 & 0.007 & 0.044 \\
\hline 2000 & 0.094 & 0.013 & 0.195 & 1.175 & 0.807 & 1.203 & 0.000 & 0.059 \\
\hline 2001 & 0.139 & 0.012 & 0.005 & 1.238 & 0.834 & 3.453 & 0.002 & 0.092 \\
\hline 2002 & 0.172 & 0.011 & 0.010 & 1.191 & 0.845 & 2.191 & 0.003 & 0.106 \\
\hline 2003 & 0.007 & 0.014 & 0.017 & 0.994 & 0.875 & 1.025 & 0.003 & 0.254 \\
\hline 2004 & 0.044 & 0.076 & 0.017 & 0.945 & 0.852 & 1.765 & 0.005 & 0.367 \\
\hline 2005 & 0.106 & 0.135 & 0.007 & 0.855 & 0.844 & 2.174 & 0.027 & 0.357 \\
\hline 2006 & 0.367 & 0.091 & 0.067 & 0.767 & 0.835 & 2.159 & 0.008 & 1.978 \\
\hline 2007 & 0.254 & 0.140 & 0.022 & 0.670 & 0.814 & 2.651 & 0.026 & 2.222 \\
\hline 2008 & 0.092 & 0.128 & 0.037 & 0.664 & 0.742 & 2.816 & 0.013 & 2.457 \\
\hline 2009 & 0.059 & 0.132 & 0.027 & 0.559 & 0.775 & 2.807 & 0.039 & 0.686 \\
\hline
\end{tabular}

Source: Author's own calculations with data from UN COMTRADE, Bank of Albania, and the Albanian Institute of Statistics

Table 2: Intra Industry Trade Index of Albania with Respective Countries

\begin{tabular}{|c|c|c|c|c|c|c|c|c|}
\hline Year & $\mathrm{BiH}$ & Bulgaria & Croatia & Greece & Italy & FYROM & Romania & Serbia \\
\hline 1996 & 0.496 & 0.002 & 0.195 & 0.252 & 0.488 & 0.513 & 0.013 & 0.604 \\
\hline 1997 & 0.436 & 0.003 & 0.648 & 0.294 & 0.382 & 0.441 & 0.052 & 0.537 \\
\hline 1998 & 0.714 & 0.009 & 0.380 & 0.302 & 0.511 & 0.433 & 0.143 & 0.754 \\
\hline 1999 & 0.370 & 0.002 & 0.070 & 0.300 & 0.775 & 0.372 & 0.029 & 0.341 \\
\hline 2000 & 0.217 & 0.006 & 0.206 & 0.207 & 0.650 & 0.185 & 0.001 & 0.816 \\
\hline 2001 & 0.191 & 0.007 & 0.006 & 0.203 & 0.676 & 0.591 & 0.006 & 0.949 \\
\hline 2002 & 0.196 & 0.007 & 0.007 & 0.230 & 0.626 & 0.462 & 0.007 & 0.538 \\
\hline 2003 & 0.064 & 0.009 & 0.022 & 0.266 & 0.699 & 0.714 & 0.010 & 0.984 \\
\hline 2004 & 0.481 & 0.067 & 0.027 & 0.291 & 0.740 & 0.477 & 0.044 & 0.292 \\
\hline 2005 & 0.495 & 0.094 & 0.012 & 0.276 & 0.767 & 0.487 & 0.154 & 0.506 \\
\hline 2006 & 0.686 & 0.077 & 0.098 & 0.273 & 0.803 & 0.467 & 0.025 & 0.908 \\
\hline 2007 & 0.511 & 0.181 & 0.047 & 0.256 & 0.784 & 0.286 & 0.304 & 0.943 \\
\hline 2008 & 0.260 & 0.173 & 0.083 & 0.269 & 0.752 & 0.274 & 0.144 & 0.989 \\
\hline 2009 & 0.183 & 0.143 & 0.054 & 0.205 & 0.731 & 0.399 & 0.222 & 0.443 \\
\hline
\end{tabular}

Source: Author's own calculations with data from UN COMTRADE, Bank of Albania, and the Albanian Institute of Statistics

\subsection{Methodology}

The panel data is comprised of countries and variables that vary over a certain time period, and this renders panel data analysis methods necessary. It is reasonable to expect that macroeconomic variables vary over time and across countries, and the choice of the appropriate panel data model to use for estimation will depend highly on the type of answers that we are looking for, as well as the Hausman test results.

A fixed effects model within estimators is used, noting that the consistency of fixed effects models is preferred to the efficiency of random effects models. In this study, the idea of interest is to analyze the effect of our variables in an integrated mode, meaning that we are not particularly interested in the fluctuations of the coefficient for a particular country, seeing that country as a sample. On the contrary, we would like to know the effect of economic integration on the level of economic growth of an entire region, not the individual effects of specific countries. In addition, although our observations are not very large, they are sufficiently broad so that we can spare some efficiency for consistency. The 
countries sample in this case is also the population, so that no inferences are required to spill from the sample to the population (which would be the case for random effects models (Verbeek, 2000)). Greene (2007) also asserts that fixed effects models are more suitable to unbalanced panels.

Moreover, the within estimator is econometrically robust and explores variations over time and allows us to answer two central questions of this study: what and how much is the growth effect of a country integrating internationally into a group of countries?

To support the choice of fixed effects within estimator, a Hausman test is conducted. The central idea of the Hausman test (Hausman, 1984) is to compare an efficient model to a less efficient but consistent model to see whether both estimation results stand. First, a fixed effects model is estimated and its coefficients are stored. Next, a random effects model is estimated and its coefficients are also stored. Next, the coefficients of both estimations are compared, and Hausman's null hypothesis - that the coefficients estimated by the random effects model are the same as the coefficients estimated by the fixed effects model - is evaluated. Test results are given in table 3 below. The test results show that the null hypothesis is rejected at the $5 \%$ confidence level with a significant p-value smaller than 0.05 .

Table 3: Hausman Test Results (with Stata 11)

\begin{tabular}{|c|c|c|c|c|}
\hline \multirow[t]{2}{*}{ Variables } & \multicolumn{4}{|c|}{ Coefficients } \\
\hline & $\begin{array}{c}\text { (b) } \\
\text { Random }\end{array}$ & $\begin{array}{l}(B) \\
\text { Fixed }\end{array}$ & $\begin{array}{c}\text { (b)-(B) } \\
\text { Difference }\end{array}$ & $\begin{array}{l}\text { sqrt }\left(\operatorname{diag}\left(V_{-} b-V_{-} B\right)\right) \\
\text { Standard Errors }\end{array}$ \\
\hline FDIR & 0.580 & 1.398 & $(0.817)$ & 0.552 \\
\hline POPG & 7.865 & 0.107 & 7.759 & 2.710 \\
\hline TRAD & (2.861) & (2.184) & $(0.677)$ & 2.564 \\
\hline EXP & 2.493 & 2.032 & 0.461 & 1.218 \\
\hline IMP & (0.059) & 0.673 & $(0.732)$ & 1.380 \\
\hline ETPR & 0.555 & (0.793) & 1.349 & 0.160 \\
\hline GEXP & $(0.212)$ & $(0.290)$ & 0.079 & 0.126 \\
\hline TII & 0.108 & 0.088 & 0.020 & \\
\hline IIT & 0.100 & 0.088 & 0.012 & 0.042 \\
\hline GERS & 9.401 & 6.200 & 3.201 & \\
\hline GERD & $(0.129)$ & $(0.434)$ & 0.305 & \\
\hline \multicolumn{5}{|c|}{$\begin{array}{l}\mathrm{b}=\text { consistent under } \mathrm{Ho} \text { and } \mathrm{Ha} ; \\
\mathrm{B}=\text { inconsistent under } \mathrm{Ha} \text {, efficient under } \mathrm{Ho}\end{array}$} \\
\hline \multicolumn{5}{|c|}{ Test: Ho: difference in coefficients not systematic; } \\
\hline $\operatorname{chi} 2(11)=(1$ & $-\mathrm{V}(\mathrm{B})^{\wedge}(-1)$ & 020 & 0.0000 & \\
\hline
\end{tabular}

Finally, a stationary test is used to check whether the panel data have unit roots, a safeguard test against spurious regression results. In this phase of the paper we follow the same path of Economidou et al. (2006) and Im et al. (2003), and use the Im, Pesaran, and Shin method for panel unit root testing. Levin et al., (2002) show that the IPS test is preferred because of its power and fewer restrictions. Economidou et al. (2006) add that the IPS test allows for heterogeneity between units in a dynamic panel framework (which is what is sought in this paper) and it is based on Augmented Dickey-Fuller regressions. The results of the unit root test are shown in Table 4 below and all variables are reported with a linear trend. At the $5 \%$ level of significance, the null hypothesis of the series having unit roots is rejected, and therefore the panel does not need differencing of orders higher than zero.

Table 4: Panel Unit Root Test (with Eviews 5)

\begin{tabular}{|l|c|c|c|c|}
\hline \multicolumn{4}{|l|}{ Variables: ETPR, EXPO, FDIR, GDPC, GERD, GERS, GEXP, IIT, IMP, POPG, TII, TRAD } \\
\hline \multicolumn{1}{|c|}{ Method } & Statistic & Prob. ${ }^{*}$ & Cross-sections & Observations \\
\hline $\begin{array}{l}\text { Im, Pesaran, and Shin W-stat } \\
\text { Null: Unit root (assumes individual unit root process) }\end{array}$ & -4.4623 & 0.0000 & 9 & \multirow{2}{*}{1386} \\
\hline${ }^{*}$ Test assumes asymptotic normality & & \\
\hline
\end{tabular}

\section{Data}

The data used has annual frequency and comes from various sources. The bulk of the data that describes the initial state of the economy - government expenditures, trade volume, exports and imports, and growth rate of GDP per capita is taken from World Bank's and OECD's National Accounts data files. The employment to population ratio is taken from the Key Indicators of the Labor Market database of the International Labor Organization. Data on the level of net FDI inflows 
is taken from the International Financial Statistics and Balance of Payments database of the International Monetary Fund. Demographic data like the annual rate of population growth is derived from total population data from United Nations' Population Division and World Population Prospects databases. The cross tables for the trade intensity index and the intra industry trade index are built with data from UNCOMTRADE and methodological support from the World Bank's Handbook on Development, Trade, and the WTO. Data on human capital stock and the level of R\&D expenditures for firms is taken from UNESCO's Institute for Statistics. Missing data for Albania's firm expenditures on R\&D were taken from the Albanian Statistical Institute business surveys in 2006, 2007 and 2008.

The cross sectional dimension has 9 developing countries, all belonging to the region that is typically classified as Southeastern Europe. All nine countries have some trade interaction with each other and share similar geographical patterns. The time period under study covers data from 1996 to 2009, the largest period for which data were semicompletely available and with which we could build a strongly balanced panel (albeit not fully balanced).

\section{Estimation Results}

Estimation results for all countries and all variables are given in table 5. There are 6 models built. The first model (1) is a baseline model where effects of FDI, trade, and international integration are not controlled for. The second model (2) adds international investment in the baseline model, while models (3)-(4) and (5)-(6) include general aspects of trade and economic integration effects on growth.

The findings in models (1) and (2) indicate that the ratio of total employment to the population is consistently significant and negative, which conforms to our expectations about the effects of labor force availability. This finding suggests that in a developing economy, employment uncertainty encourages high retention rates, despite shifting factors of reward and recognition. Therefore, it might be harder for companies entering a new market to find readily available labor that is on stand-by and not currently utilized. Waiting for the domestic labor turnover cycle to play out certainly adds to start-up costs, and might deter FDI to follow through. On the other hand, findings on gross enrollment ratio for secondary schooling confirm the conviction that a more competent labor force has a significant positive influence on growth. This adds to the point that labor in a new market has to be readily available, as well as posses a required level of professional competency. The interaction between domestic government expenditures and foreign direct investment is an interesting one. Results show that government expenditures undermine growth when FDI is the only international integration variable controlled for, and it seems that developing countries would benefit much more from increased FDI volume rather than government spending. The influence of FDI on growth seems to be consistently significant and positive, in line with our expectations. Lastly, it seems that the level of R\&D expenditures does not influence growth. Pelegrin and Bolance (2008) find that for cost-oriented industries it is much more important to find affordable labor and enough factor endowments, and that knowledge flows are attracted to regions with mature local innovation systems. Industries in SEE countries are mainly cost-oriented and work less in tech-intense sectors, as well as local innovation systems in the region are in their early stages of development.

When the impact of trade on growth is considered in models (3) and (4), it seems that higher trade volume leads to higher growth rates for the economies of Southeastern Europe. Adding more to this effect, the dissection of trade shows that it is exports that influence growth positively, and imports, although insignificant in terms of statistical significance, have a negative coefficient. The coefficient on FDI diminishes when trade is controlled for, but it stays positive, suggesting that developing economies in SEE benefit considerably more from trade than from international investments. However, it might be the case that countries of Southeastern Europe may have struck Narula's (2001), Balasubramanyam et al.'s (2002), and Xu's (2000) minimal threshold level of an efficient labor market (including human capital stock), and of an adequate absorptive capacity ${ }^{9}$ that is able to exploit the positive externalities of FDI, after which point benefits from FDI occur. Economidou et al. (2006) point out that for least developing countries internal integration arrangements can do little to attract FDI in the absence of appropriate economic structures. SEE countries are all classified as developing or highly developing ${ }^{10}$ countries and this might explain a minimum difference between our and the preceding author's findings. Lastly, the influence of exports and FDI on growth seems to be comparably positive in model (4).

In models (5) and (6) we control for international integration variables. There are no major differences in influence on growth from the ratio of total employment to population and from the level of secondary schooling. However, gross R\&D expenses gain significance when trade intensity and particularly intra industry trade are both controlled for. Intra

\footnotetext{
${ }^{9}$ Macroeconomic management: inflation, debt, openness, infrastructure, education, etc

10 United Nations Human Development Report (2009)
} 
industry trade is argued to promote industrialization. Nevertheless, higher R\&D expenditures add a financial burden to any start-up process in the context of cost-oriented economies. These results should be taken with a grain of caution however, because the data do not differentiate on the type of R\&D expense and it is impossible to make strong statements about the effect of international integration on R\&D and, subsequently, on growth. Meanwhile, it seems that this effect of R\&D on growth necessitates the mutual presence of intra industry trade and of larger-than-expected bilateral trade flows. So, if we could differentiate on types of R\&D expenses we could evaluate a region's growth benefits from local innovation systems and investments in R\&D from international integration. In both models (5) and (6) FDI and exports intensify their positive influence on growth when international integration variables are controlled for, which shows that an integrated region benefits more from international investments and trade in the form of exports. In model (5) we see that imports have gained significance and that they affect growth negatively when trade intensity in the region is higher than expected given the region's weight in world trade. The argument behind this finding might be that larger trade openness in general does not filter exports over imports, but rather allows all forms of trade to occur, and it seems that imports reach demand faster than exports do. A deeper analysis of the interaction between these two variables will require a later study at the micro level, where we could see what kind of exports and what kind of imports cause these effects in the region. In models 5 and 6 , international integration seems to power up the concurrent effect of FDI and Exports. FDI seem to be attracted to an integrated region more intensively compared to a region with just trade in the common sense, as shown in models 3 and 4 . However, the IIT coefficient does not seem to be significant, and this might suggest that there are no clear indications of any industrial cluster currently working or being formed in Southeastern Europe.

Lastly, the annual growth rate of the population was not found statistically significant in any case, and it might be the case that demographic variables require wider time spans than 13 years to fluctuate enough that we could study their effect on growth.

\section{Conclusions}

International integration is explored through a sample of 9 countries in Southeastern Europe for a period of 13 years, from 1996 to 2009. The central questions of this study are to assess the directional effect of international integration on growth, to study the channels of transmission of such growth, and to measure the intensity of these relationships.

The findings suggest that: an integrated region benefits more from trade in the form of exports, and less so from imports. Foreign direct investments are attracted to an integrated region more intensively, although inter-regional R\&D expenditures in cost-oriented industries are not influencing growth to a considerable extent. The difference between hightech and low-tech investments might give more conclusive results regarding this matter. For an integrated region where FDI and trade are intense, a competent and readily available labor force is found to affect growth incrementally more.

Table 5: Fixed-Effect Coefficient Estimations

\begin{tabular}{|c|c|c|c|c|c|c|}
\hline Variables & \multicolumn{6}{|c|}{ Models } \\
\hline Real GDP per Capita Growth & $\frac{\text { Baseline }}{(1)}$ & $\frac{F D I}{(2)}$ & \multicolumn{2}{|c|}{$\frac{\text { Trade Effect }}{(3)(4)}$} & \multicolumn{2}{|c|}{$\frac{\text { International Integration }}{(5)(6)}$} \\
\hline POPG & $-0.151(0.842)$ & $-0.168(0.361)$ & $-0.202(0.312)$ & $0.749(0.443)$ & $-0.305(2.379)$ & $-0.151(2.361)$ \\
\hline ETPR & $-0.939 * *(0.402)$ & $-0.893^{*}(0.333)$ & $-0.796^{* \star}(0.318)$ & $-0.669^{* *}(0.309)$ & $-0.884^{*}(0.297)$ & $-0.826^{\star}(0.297)$ \\
\hline GEXP & $-0.462(0.279)$ & $-0.549^{* \star}(0.232)$ & $-0.461 * *(0.221)$ & $-0.239(0.225)$ & $-0.328(0.217)$ & $-0.314(0.216)$ \\
\hline GERS & $0.866^{*}(0.393)$ & $0.378^{\star}(0.157)$ & $0.743^{*}(0.113)$ & $0.701^{*}(0.076)$ & $0.742^{*}(0.060)$ & $0.380 *(0.075)$ \\
\hline GERD & $0.079(0.152)$ & $0.117(0.126)$ & $0.126(0.120)$ & $-0.149(0.145)$ & $-0.316(0.194)$ & $-0.392 *(0.198)$ \\
\hline FDIR & & $0.886^{\star}(0.401)$ & $0.084^{*}(0.041)$ & $0.137^{*}(0.043)$ & $0.718^{*}(0.249)$ & $0.473^{*}(0.137)$ \\
\hline TRAD & & & $0.942^{\star}(0.261)$ & & & \\
\hline EXP & & & & $0.283^{*}(0.033)$ & $0.052^{*}(0.019)$ & $0.239 *(0.117)$ \\
\hline IMP & & & & $-0.313(0.357)$ & $-0.637^{* \star \star}(0.354)$ & $-0.698^{\star \star \star}(0.354)$ \\
\hline TII & & & & & $0.149 *(0.033)$ & $0.093^{\star \star \star}(0.049)$ \\
\hline IIT & & & & & & $0.087(0.054)$ \\
\hline Observations & 126 & 126 & 126 & 126 & 112 & 112 \\
\hline$R^{2}$ within & 0.227 & 0.473 & 0.529 & 0.566 & 0.613 & 0.624 \\
\hline$F$-test & 6.57 & 16.59 & 17.63 & 17.80 & 16.75 & 15.59 \\
\hline
\end{tabular}




\section{References}

Ades, Alberto F. and Edward L. Glaeser, 1995, "Trade and Circuses: Explaining Urban Giants," Quarterly Journal of Economics, 110(1): 195-227.

Balasubramanyam, V.N., M. Salisu, and D. Sapsford, 1996, "Foreign Direct Investment and Growth in EP and IS Countries," Economic Journal, Vol.106, pp. 92-105.

Balasubramanyam, V.N., M. Salisu, and D. Sapsford, 1999, "Foreign Direct Investment as an Engine of Growth," Journal of International Trade and Economic Development, Vol.8 (1), pp. 27-40.

Balasubramanyam, V. N.; Sapsford, D.; Griffith, D., 2002, "Regional Integration Agreements and Foreign Direct Investment: Theory and Preliminary Evidence," Manchester School, 70 (3), pp. 460-82.

Baldwin, Richard E. And Philippe Martin, 2004, "Agglomeration and Regional Growth," Urban Economics, Vol. 4: Cities and Geography, Elsevier North-Holland.

Barro, R. J., Sala-I-Martin, X. Economic Growth, Boston, Massachusetts: McGraw Hill Inc, 1995.

Bertinelli, Luisito and Duncan Black, 2004, "Urbanization and Growth," Journal Of Urban Economics, 56(1): 80-96.

Blomstrom, M., R.E. Lipsey, and M. Zejan, 1994, "What Explains Developing Country Growth?", NBER Working Paper No. 4132.

Borenzstein, E., J. De Gregorio, And J.W. Lee, 1995, "How Does FDI Affect Economic Growth?", NBER Working Paper No. 5057.

Bosworth, B. and S. Collins, 1999, "Capital Inflows, Investment, and Growth," Tokyo Club Papers, Vol. 12, pp. 55-72.

Brülhart, Marius and Federica Sbergami, 2009, "Agglomeration and Growth: Cross-Country Evidence," Journal of Urban Economics, 65(1): 48-63.

Criscuolo P., Narula R. And Verspagen B., 2005, "Role of Home and Host Country Innovation Systems in R\&D Internationalization: A Patent Citation Analysis", Economics of Innovation and New Technology, Vol. 14, pp. 417-433.

Crozet, Matthieu, and Pamina Koenig, 2007, "The Cohesion Vs Growth Tradeo": Evidence from EU Regions, mimeo, University Of Paris 1.

Culem C. G., 1988, "The Locational Determinants of Foreign Direct Investments among Industrialized Countries," European Economic Review, 32, pp. 885-904.

De Mello, L.R., 1996, "Foreign Direct Investment, International Knowledge Transfers, And Endogenous Growth: Time Series Evidence," Mimeo (Kent, England: Department Of Economics, University Of Kent).

Dees, S., 1998, "FDI in China: Determinants And Effects," Economics of Planning, Vol. 31, pp. 175-194.

Driffield N. and Munday M., 2000, "Industrial Performance, Agglomeration, and Foreign Manufacturing Investment," Journal of International Business Studies, 31, pp. 21-37.

Economidou, C., V. Lei, and J.S. Netz, 2006, "International Integration And Growth: A Further Investigation On Developing Countries," International Advances In Economic Research, Vol. 12, pp. 435-448.

Egea P. and Lo' Pez Pueyo C., 1991, "Un Estudio Sobre La Distribucio’N Geogra'Fica De La Inversio’N Extranjera Directa En Españ A," Informacio’N Comercial EspañOla, No. 696-697, pp. 105-118.

Frankel, J.: Romer, D., 1999, "Does Trade Cause Growth?" American Economic Review, 89 (3) pp. 379-99.

Fujita, M., P. Krugman, A. Venables, The Spatial Economy, Cambridge: Mit-Press, 1999.

Fujita, M. and Krugman, P. (2004), "The new economic geography: Past, present and the future." Papers in Regional Science, 83, pp. 139-164.

Greene, W.H., Econometric Analysis, Prentice Hall, 2007

Guimaraes P., Figueiredo O. and Woodward D., 2000, "Agglomeration and the Location of Direct Investment in Portugal," Journal of Urban Economics, 47, pp. 115-135.

Hausman, J. and D. Mcfadden, 1984, "Specification Tests For The Multinomial Logit Model," Econometrica, Vol. 52, No. 5, Pp. 1219-1240.

Haveman, J. D., Lei, V., Netz, J. S., 2001, "International Integration and Growth: A Survey and Empirical Investigation," Review of Development Economics, $5(2)$, pp. 289-311.

Henderson, J. Vernon, 2003, "The Urbanization Process and Economic Growth: The So-What Question," Journal of Economic Growth, 8(1): 47-71.

Hill, S. and Munday, M., 1991, "The Determinants of Inward Investment: A Welsh Analysis," Applied Economics 54, pp. 258-266.

Hill S. and Munday M., 1992, "The UK Distribution of Foreign Direct Investment: Analysis and Determinants," Regional Studies 26, pp. 535-544.

Hoekman, Bernard, Philip English and Aaditya Matoo (Editors), 2003, Development, Trade and the WTO: A Handbook. Washington, D.C.: Worldbank.

Im, K., Pesaran, H., Shin Y., 2003, "Testing For Unit Roots In Heterogeneous Panels," Journal of Econometrics, 115, pp. 53-74.

Krueger, A., Lindahl, M., 2001, "Education and Growth: Why and For Whom?" Journal of Economic Literature, Vol. 39(4), pp. 1101-36.

Krugman P., 1991, "Increasing Returns and Economic Geography," Journal of Political Economy, 99, pp. 483-499.

Kawai, H., 1994, "International Comparative Analysis of Economic Growth: Trade Liberalization and Productivity," Developing Economies, Vol. 32, pp.372-97.

Lucas, R. E. Jr., 1993, "Making a Miracle," Econometrica, Vol. 61(2), pp. 251-72.

Mariotti S. and Piscitello L., 1995, "Information Costs and Location of FDI within the Host Country: Empirical Evidence from Italy," Journal of International Business Studies, 26, pp. 815-841.

Marshall A., Principles of Economics. New Haven, Ct., Yale University Press, 1920.

Martin C., 1999, "The technological position of the Spanish economy in Europe. A global Evolution," Papers of Spanish Economy, Vol. 81, pp. 2-19.

Maurseth B. and Verspagen B., 2002, "Knowledge Spillovers in Europe: A Patent Citation Analysis," Scandinavian Journal of Economics, 104, pp. 531-545.

Narula, R., 2001, "Multinational Firms, Regional Integration and Globalizing Markets: Implications For Developing Countries," Merit-Infonomics Research Memorandum Series, The Netherlands, pp. -36.

Narula R. and Zanfei A., 2004, "Globalization of Innovation: the Role of Multinational Enterprises. In Fagerberg J., Mowery D. And Nelson R. (Eds) Handbook of Innovation. Oxford University Press, Oxford.

Pelegrin A., 2002, "Regional FDI location determinants," Papers of Spanish Economy, Vol. 93, pp. 122-134.

Pelegrin, A. and Catarina Bolance, 2008, "Regional Foreign Direct Investment in Manufacturing: Do Agglomeration Economies Matter?" Regional Studies, Vol. 42.(4), pp. 505-522, May 2008.

Rodrik, D., 1999, "The New Global Economy and Developing Countries: Making Openness Work," Policy Essay No.24,Overseas Development Council, Washington, DC Rosenthal, Stuart S. and William C. Strange, 2001, "The Determinants of Agglomeration," Journal of Urban Economics, 50(2): 191-229.

Scaperlanda, A. and Balough R. S., 1983, "Determinants of U.S. Investment in the E.E.C.," European Economic Review, 21, pp. 381-390.

Shavier, J.M., and F. Flyer, 2000, "Agglomeration Economies, Firm Heterogeneity, and FDl in the United States," Strategic Management Journal, Vol. 21, pp. 1175-1193.

Thiran, J. M. And Yamawaki H., 1995, "Regional and Country Determinants of Locational Decisions: Japanese Multinationals in European Manufacturing." The Institute of European Studies, The Queen's University of Belfast.

United Nations Conference on Trade and Development (UNCTAD). "World Investment Report, Foreign Direct Investment and the Challenge of Development," New York: United Nations, 1999.

United Nations Development Program, UN Human Development Report, New York: United Nations, 2009.

Verbeek, M., A Guide To Modern Econometrics, West Sussex, England: John Wiley And Sons, 2000.

Williamson, JeRey G., 1965, "Regional Inequality and the Process of National Development," Economic Development and Cultural Change, $13(4)$ : 3-45. Xu, B., 2000, "Multinational Enterprises, Technology Diffusion, and Host Country Productivity Growth," Journal of Development Economics, 62, pp. 477-93. 